\title{
Treatment of cystic craniopharyngiomas with yttrium-90 colloid solution.
}

Jenö Julow, Dr. med. habil., Ferenc Lányi, M.D., Márta Hajda, M.D., György T. Szeifert, M.D., Ph.D., Katalin Bálint, M.D., Gábor Drasny, Emil Pásztor, Imre Fedorcsák, M.D., Ph.D., Katalin Borbély, Dr. med. habil., and István Nyáry, Dr. med. habil.

Department of Neurosurgery, St. John's Hospital; National Institute of Neurosurgery; Budapest, Hungary; and Department of Mathematics, Eötvös Lóránd University, Budapest, Hungary

The authors analyzed long-term follow-up data to assess the value of intracavitary irradiation with stereotactically implanted beta-emitting radioisotope ${ }^{90} \mathrm{Y}$-silicate colloid for the treatment of craniopharyngiomas. Fifty-seven craniopharyngiomas in 42 patients were selected for retrospective analysis. The yttrium-90 was implanted intracavitally, using computerized tomography-guided and three-dimensional stereotactic treatment planning. The cumulative dose aimed at the inner surface of the cyst wall was $300 \mathrm{~Gy}$.

An average of $75 \%$ shrinkage of the initial cyst volume was observed. In 18 cases the reduction was more than $91 \%$, and the cyst disappeared totally in 11 cases.

A 50\% decrease in cyst volume was usually apparent between the 2 nd and 4 th months. A $70 \%$ decrease in cyst volume was seen by the 5th and 6th months and an $80 \%$ reduction by the 7 th and 8 th months. Cysts that were unchanged remained so throughout the observation period. The time course of volume reduction could be expressed mathematically by the formula of $0.73 \mathrm{X} \mathrm{e}^{-0.62 X \mathrm{~T}}+0.27$, where "e" is the basic number of natural logarithm and " $\mathrm{T}$ " is the time expressed in months. Mean survival duration after intracavitary irradiation was 9.4 years.

The shrinkage of the cyst was a consequence of fibrosis of the wall, as seen on histopathological examination. The neuroophthalmological prognosis was favorable only when the optic disc was normal or nearly normal at the time of the treatment. In the presence of preexisting optic atrophy, visual deterioration proved to be irreversible. The long-term results support the view that intracavitary ${ }^{90} \mathrm{Y}$-irradiation is a noninvasive and very effective method of treatment for craniopharyngioma cysts. Because of the $1.1 \mathrm{~mm}$ half-life decay of beta irradiation, it cannot influence the solid part of the tumor; therefore, the best result can be expected in solitary cysts.

Key Words * yttrium-90 silicate colloid * cystic craniopharyngioma * cyst * intracavital/intracavitary irradiation * intracavital/intracavitary brachytherapy * intracavital/intracavitary radiosurgery 
The sheer number of methods for treating craniopharyngiomas (surgical extirpation, aspiration of cyst fluid, shunt operations, external irradiation and radiosurgery, general and intracystic chemotherapy, hormone substitution, intracavitary irradiation, and combinations of the above) indicates that none of the existing treatments is the exclusive modality of choice, and even the phrase "multi-modality management of craniopharyngiomas" is misleading because there is yet no satisfactory state-of-the-art treatment.

In the present study we analyze our results with the intracavitary implantation of ${ }^{90} \mathrm{Y}$-silicate colloid (Amersham, England) and ${ }^{90} \mathrm{Y}$-citrate colloid (CIS, France) following partial tumor resection, usually through a frontotemporal craniotomy. The procedure devised by Leksell,[26,27] Wycis,[53] and further developed by Backlund[1-3,42] has been used by us since 1975. The aim of the present study is to assess the volume changes in the treated cysts, the time course of volume reduction, and the ophthalmological signs.

\section{CLINICAL MATERIAL AND METHODS}

From December 1975 to July 1994 we performed 60 yttrium-90 implantations into craniopharyngioma cysts in 45 patients. We treated mostly recurrent cysts, following one or repeated surgical procedures, and we analyzed the data of 57 procedures in 42 patients. Preliminary data of parts of this study have been published previously.[16-19,46,47] The median age of patients was 24.3 years (range 4-66 years.). There were 14 female and 28 male patients. The first patient was treated 20 years ago and the most recent patient had a follow-up period of 18 months. Forty patients had operations prior to yttrium-90 implantation, whereas in two cases, yttrium-90 implantation was the primary treatment.

Following routine neuroradiological and neurosurgical examination of the patient, cyst volume was determined by computerized tomography (CT) (in the early days of the treatment, by cystography or isotope dilution methods).[11,22,32,44] In the cases of cystography the volume has been calculated from the 3 diameters measured after the positive contrast and air cystography by the formula of simple ellipsoidal volume calculation: $4 \mathrm{r}^{3 * 1 / 2 / 3} \gg 0.52 * \mathrm{x} / 2 * \mathrm{y} / 2 * \mathrm{z} / 2$. The enlargement factor was taken into consideration. Since 1980 the cyst volume has been calculated by CT volumetric analysis alone. Computerized tomography scanning of cysts was performed $(2.5-\mathrm{mm}$ thick slices with table increments of $2 \mathrm{~mm}$ ). On each slice, the area of cyst was measured in square centimeters. The sum of the area was multiplied by the slice thickness to give the volume in cubic centimeters. The measurement of volume was used for the calculation of radioactivity to be injected. The application was by a technique comparable to the Backlund method.[2,3] The calculations were performed by our own microcomputer program.[16] Our dosimetry was also based on the Loevinger formula,[29] as done by other authors as well.[2,5,21,26,33,35,40,48,52] Implantation of ${ }^{90} \mathrm{Y}$ into the cyst was performed through a frontal burr hole or by transsphenoidal puncture. In the initial cases we used a free-handed technique; however, since 1989 we have applied stereotactic techniques using Leksell and Riechert-Mundinger frames. The mean dose delivered to the cyst wall was $302 \mathrm{~Gy}$. To detect possible leakage of the isotope we performed gamma camera examinations in all cases following implantation, detecting the "Bremsstrahlung."[5] Cyst shrinkage was monitored by repeated CT examinations (by cystography or autopsy during earlier years). The time course of postirradiation relative volume reduction (VR) was analyzed by 88 measurements obtained from CT scanning of cyst volume in 33 patients (Fig. 1). To simplify representation, the initial original cyst volume (OCV) was normalized to $100 \%$ in all cases. The curve shows the sequence of the average reduction of the relative cyst volume calculated by linear interpolation of $88 \mathrm{CT}$ volume measurements with a $95 \%$ confidence interval. Beyond 9 months we had insufficient data to permit 
reliable analysis.

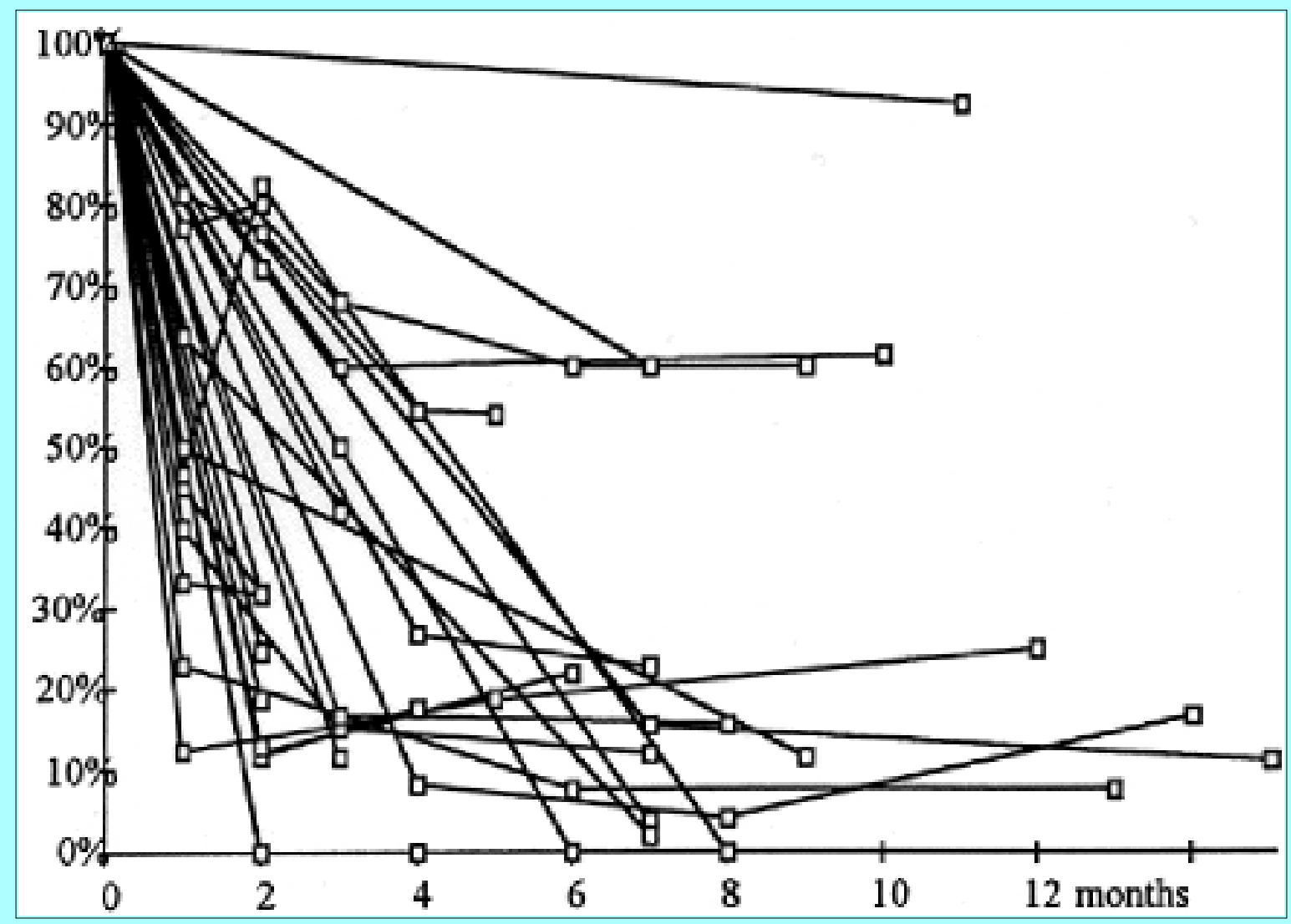

Fig. 1. Graph showing reduction of relative cyst volumes and time course postimplantation using serial CT measurements.

Histopathological examination of the cyst wall after yttrium-90 treatment was performed in seven cases. Material for light and electron microscopy was obtained at operation or autopsy.

\section{RESULTS}

In 42 patients selected for retrospective analysis a total of 57 craniopharyngioma cysts were treated with stereotactically applied intracavitary irradiation (STAIR) using yttrium-90. We implanted the yttrium-90 mainly at recurrent cysts after one or more microsurgical operations. Other centers use this method as a primary modality of management.[2,3,39] Additional treatments were performed before and/or after the ${ }^{90} \mathrm{Y}-\mathrm{STAIR}$, including resection, aspiration, and shunt placement (Table 1).

We have not observed leakage of yttrium-90 by gamma camera examination in any case.

\begin{tabular}{|c|c|c|}
\hline \multicolumn{3}{|c|}{$\begin{array}{c}\text { TABLE } 1 \\
\text { ADD TONAL TREATMENTS BEFORE AND AF TER THE FIRST 9OY-STAIR } \\
\text { TREATMENT IN 42 PATIENTS WITH CRANIOPHARYNGOMA, }\end{array}$} \\
\hline Procedure & Before 1 st $90 \mathrm{~V}$ Im plant & After 1:st $90 \mathrm{~V}$ Implant \\
\hline resection & $\begin{array}{l}34 \text { (1 resection) } \\
7(2 \text { resections }) \\
3(3 \text { resections })\end{array}$ & 10 \\
\hline $\begin{array}{l}\text { aspiration } \\
\text { shunt }\end{array}$ & $\begin{array}{c}14 \\
6\end{array}$ & $\begin{array}{l}9 \\
5\end{array}$ \\
\hline
\end{tabular}




\section{Preoperative Data}

The mean OCV preimplantation was $20.4 \mathrm{ml}$ (range $2.7-73 \mathrm{ml}$ ). In children the mean OCV preimplantation was smaller than in adults (16 vs. $22 \mathrm{ml}$, respectively). In the adamantinous and mixed histological types of cysts the mean OCV was less than in the squamous type (13.8 and $19.1 \mathrm{ml}$, respectively, vs. $22.6 \mathrm{ml}$ ).

Neuroophthalmological data before yttrium-90 treatment are presented in Table 2. Visual field defects or impairment of visual acuity were observed in 40 of 42 patients. Patients with no pre- or postoperative defect have been excluded. A unilateral optic nerve lesion was present in seven cases, chiasmal damage in 25 , and a lesion of the optic tract in eight. Only five patients had a normal optic disc. Temporal pallor was found in 13 cases, and optic atrophy was documented in 22 patients preoperatively.

\begin{tabular}{|c|c|c|c|c|c|}
\hline \multicolumn{6}{|c|}{$\begin{array}{c}\text { TABLE } 2 \\
\text { NEUROOPHTHALMOLOGICAL DATA PRE- AND POST 90Y-STAIR TREATMENT IN PATIENTS } \\
\text { WITH CRANIOPHARYNGOMA }\end{array}$} \\
\hline \multirow[b]{3}{*}{ Signs } & \multicolumn{5}{|c|}{ No. of Cases } \\
\hline & \multirow[b]{2}{*}{$\begin{array}{c}\text { Pre- } \\
\text { treatment }\end{array}$} & \multicolumn{4}{|c|}{ Postreatment } \\
\hline & & $\begin{array}{l}\text { Complete } \\
\text { Recovery }\end{array}$ & $\begin{array}{c}\text { Im- } \\
\text { proved }\end{array}$ & $\begin{array}{c}\text { Un- } \\
\text { changed }\end{array}$ & $\begin{array}{c}\text { Pro- } \\
\text { gression }\end{array}$ \\
\hline \multicolumn{6}{|l|}{ visual acuity } \\
\hline $55-5 / 2$ & 10 & 2 & 1 & 7 & 0 \\
\hline $5 / 10-550$ & 11 & 3 & 3 & 4 & 1 \\
\hline$\varnothing 550$ & 10 & 1 & 1 & 7 & 1 \\
\hline Elind & 9 & 0 & 0 & 9 & 0 \\
\hline total & 40 & 6 & 5 & 27 & 2 \\
\hline \multicolumn{6}{|l|}{ optic disc } \\
\hline normal & 5 & 2 & 2 & 1 & 0 \\
\hline temporal pallor & 13 & $\overline{3}$ & 4 & 6 & 0 \\
\hline severe pallor or atrophy & 22 & 0 & 0 & 20 & 2 \\
\hline total & 40 & 5 & 6 & 27 & 2 \\
\hline \multicolumn{6}{|l|}{ visual field le sions } \\
\hline unilateral optic nerwe & 7 & 3 & 2 & 3 & 0 \\
\hline chiasmal & 25 & 2 & 3 & 17 & 2 \\
\hline optic tract & 8 & 0 & 0 & 8 & 0 \\
\hline total & 40 & 5 & 5 & 28 & 2 \\
\hline
\end{tabular}

\section{Postoperative Results}

Cyst Volume Decrease. Following 57 yttrium-90 implantation procedures in 42 patients, shrinkage occurred in 45 cysts. Three cysts did not shrink even after repeated yttrium-90 implantation. The results of ${ }^{90}$ Y-STAIR are unknown for 9 cysts.

After ${ }^{90}$ Y-STAIR the mean OCV was reduced from 20.4 to $3.93 \mathrm{ml}$ (mean $1.5 \mathrm{ml}$ ). The total volume of all cysts after ${ }^{90} \mathrm{Y}$-STAIR diminshed from 1131.1 to $180.8 \mathrm{ml}$.

The VR of all cysts is shown in Fig. 2. The VR of the cystic part of the craniopharyngioma was more than $91 \%$ in 18 cases (within this group, the cyst disappeared totally in 11 cases). More than a 50\% VR occurred in 18 cases, a 20 to $50 \%$ reduction in five, and less than $20 \%$ in three cysts. The volume did not change in two cysts, minimally increased in one, and the changes could not be determined in nine cases. The overall mean VR in all 48 cysts was $75.02 \%$. The mean reduction in the cyst size was $76.2 \%$ in children (aged $1 \mathrm{t} 14$ years), $74.5 \%$ in adults, $73.2 \%$ in females, and $75.9 \%$ in males. A $72.4 \%$ reduction 
was seen in cysts larger than $20 \mathrm{ml}$, and a $77.1 \%$ reduction occurred in smaller cysts. The mean VR was $74.6 \%$ in primary and $76.7 \%$ in recurrent cysts. Analyzing the histological subtypes, the adamantinous cysts had the best prognosis with an $80.4 \%$ VR. In the squamous group the mean VR was $72.4 \%$, whereas it was $48.1 \%$ in the mixed type, making this the group with the worst overall prognosis. The VR was more significant $(76.2 \%)$ in 13 cysts receiving less than 302 Gy compared to those receiving more than $302 \mathrm{~Gy}$, which had a reduction of $69.8 \%$.

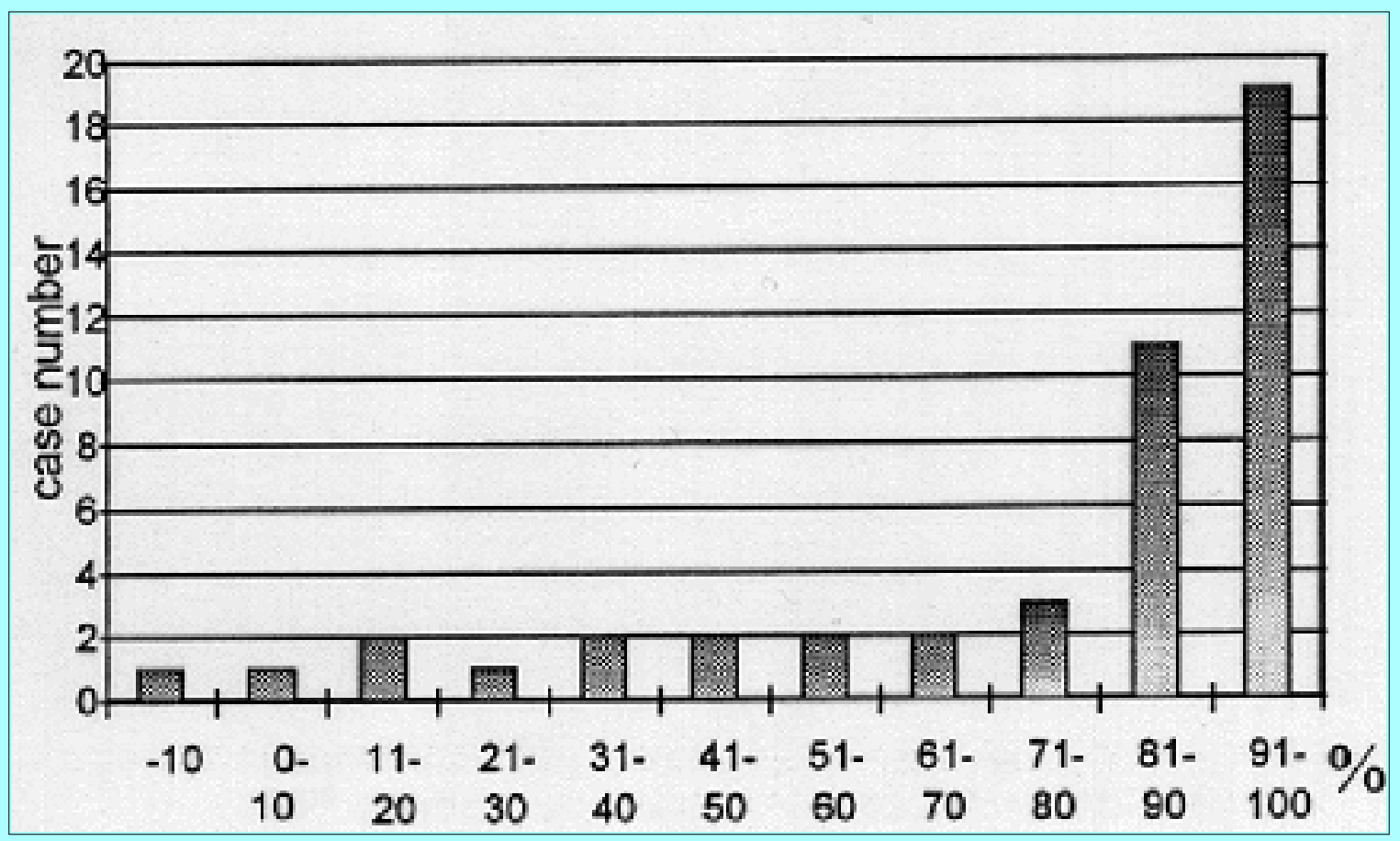

Fig. 2. Bar graph showing the frequency distribution of percent of VR. In most cases there was an 80 to $100 \%$ permanent VR after irradiation. (The two cysts without VR are not illustrated).

Following the intracavital irradiation with ${ }^{90} \mathrm{Y}$, the reduction in cyst volume was progressive to $50 \%$ between 2 and 4 months, to $70 \%$ between 5 and 6 months, and $80 \%$ in 7 and 8 months postimplantation with a $95 \%$ confidence interval (Fig. 3 continuous curve). The diminished or obliterated cysts did not change their volume over a long observation period. 


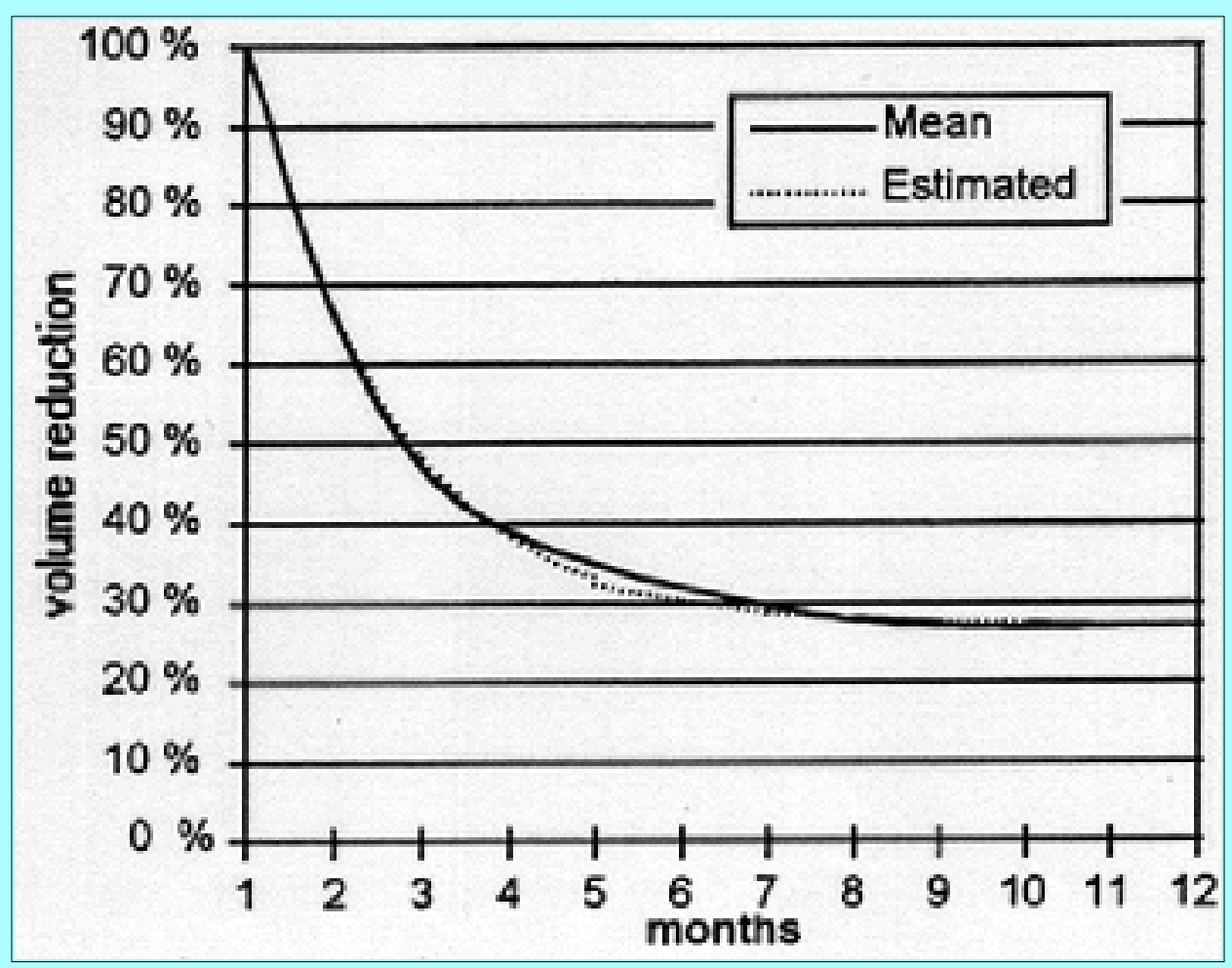

Fig. 3. Graph showing the time course of VR following ${ }^{90}$ Y-STAIR. The continuous curve shows the mean of VR based on CT measurements and estimated by our formula (dotted line).

\section{Clinical Outcome}

The mean survival time during the 20-year follow-up period (1975-1995) was 9.1 years (minimum 1.5 years, maximum 20 years). The mean survival time of the patients still living was 10.6 years and in the group of deceased patients the survival period was 3.9 years. Actuarial survival rates at 5 and 10 years were $84 \%$ and $72 \%$, respectively. Figure 4 shows the Kaplan-Meier survival analysis of our patients. The yttrium-90 was given longer than 5 years ago in 33 cases (78.5\%) and longer than 10 years ago in 13 cases $(31 \%)$. 


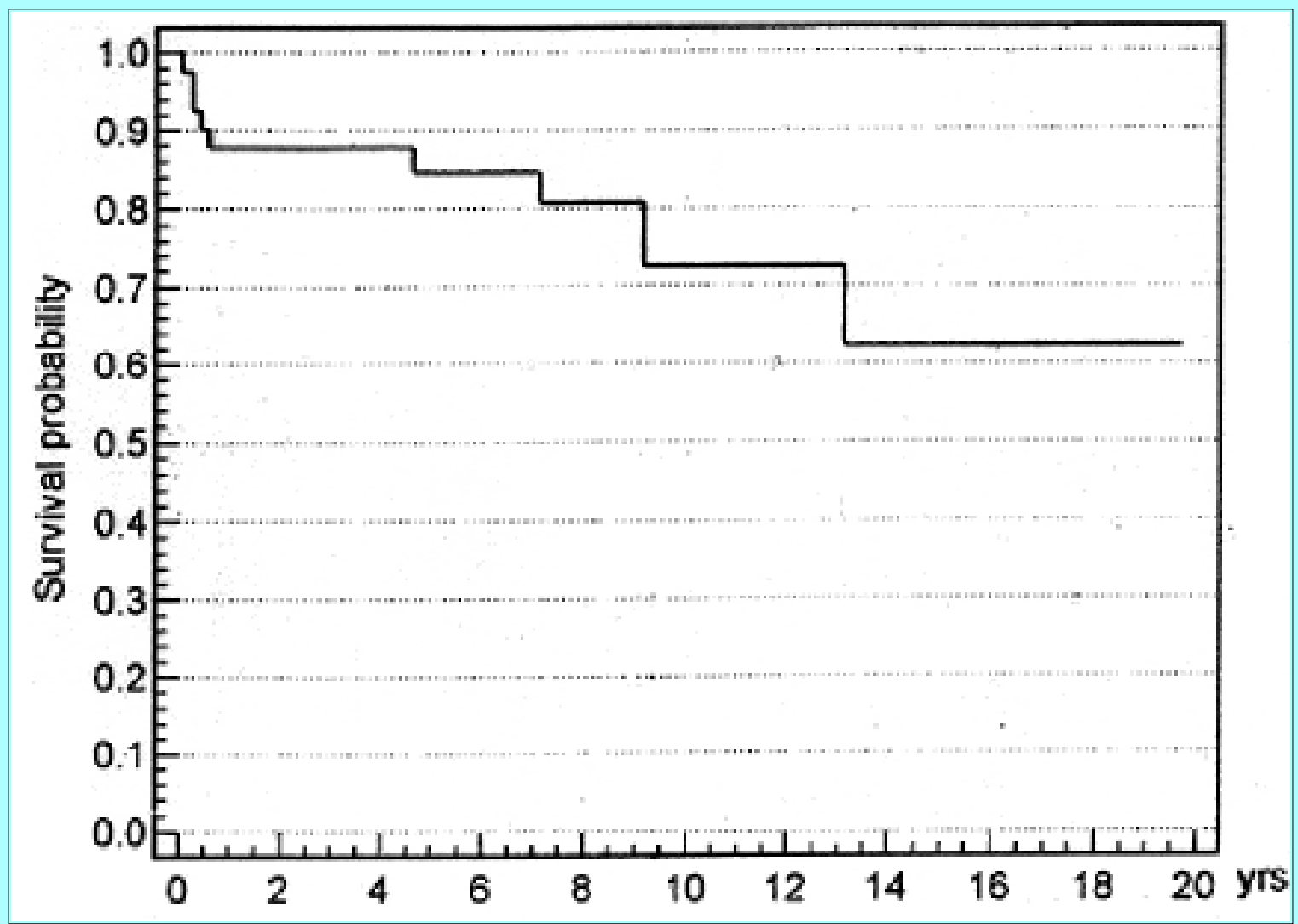

Fig. 4. Graph showing the Kaplan-Meier survival curves of this multimodality treatment: 5 -year survival was achieved in $84 \%$ and 10 -year survival was achieved in $72 \%$ of our cases.

The ${ }^{90} \mathrm{Y}$-STAIR did not result in significant changes in the neurological symptoms of our patients. There was one perioperative death from meningo ventriculitis 1.5 months after transnasal puncture; two patients died due to unrelated causes several years following treatment (one due to pulmonary embolism, one to cardiac insufficiency); and two patients died due to progression of the solid part of the craniopharyngioma several years after the procedure.

It seems obvious that our clinical results were impeded by the volume of the solid tumor. The average size of the solid part was $7.2 \mathrm{ml}$ (range 0-37 ml). There was no solid tumor at all in six cases. The volume was less than $3 \mathrm{ml}$ in five, 3 to $10 \mathrm{ml}$ in 10,10 to $20 \mathrm{ml}$ in three, and more than $20 \mathrm{ml}$ in six cases.

The neuroophthalmological signs in 40 patients, (excluding the two cases with normal pre- and postoperative examinations) are given in Table 2. After yttrium-90 therapy the status of 27 patients did not change. The ophthalmological status improved in 11 patients with thin-walled cysts. Deterioration of vision occurred in two patients: radiation damage was suspected as the cause in one and compression of the optic nerve by the solid part of the tumor in the other. Five patients had transient oculomotor nerve paresis: one occurred at the time of the puncture due to direct injury of the oculomotor nerve, and in the remaining four patients, neuropathy developed during the follow-up period.

\section{Histological Examination}

Our previous light and electron microscopy studies of the cyst wall following ${ }^{90}$ Y-irradiation revealed that the lining epithelial cell layer was damaged and that the cyst wall shrank. Thickened capillary walls 
were also seen. We found proliferation of endothelial cells and subendothelial connective tissue with focal calcification and narrowed lumens of small vessels with a large amount of thick collagen bundles showing hyaline degeneration.[46,47]

\section{DISCUSSION}

The possibilities and limitations of the intracavitary implantation of radioisotopes into craniopharyngioma cysts have been documented in the last two decades.[3,8,13,17,33] Radioisotopes emitting short-range beta radiation and with a short half-life $\mathrm{Na}^{32} \mathrm{PO}_{4}$, [27] $\mathrm{Cr}^{32} \mathrm{PO}_{4},[4,9,20,37,40,47-54]$ $\mathrm{Bi}^{32} \mathrm{PO}_{4},[28]{ }^{198} \mathrm{Au}$-colloid,[4,6,12,21,23] ${ }^{90} \mathrm{YCl}_{3}$,[7] and later with ${ }^{90} \mathrm{Y}$-silicate colloid[2,3,10,15-19,24,27,34,35,38,44,52] or 186rhenium[34-36,43,48,52] have all been used.

Our results confirm the data previously reported regarding the lasting 74 to $100 \%$ decrease in volume following high-energy beta irradiation of cystic craniopharyngiomas. $[3,31,34,39,44]$ In our study the mean value of the decrease of OCV measured by CT was $75.1 \%$. Of the 48 cysts irradiated and afterwards controlled, $61 \%$ showed more than an $80 \%$ decrease of the OCV, with complete disappearance in $23 \%$. In $27 \%$ of the irradiated cysts the VR has been between $40 \%$ and $80 \%$. Less than a $40 \%$ decrease occurred in $10.6 \%$ of the cases. In $6.5 \%$ of the cysts shrinkage was not significant, and the mean residual volume was $25 \%$ of the OCV. Even these cases of volumetrically poor results, with only arrest of steady increase in cyst size as opposed to an actual decrease, nevertheless proved to be important to the patient.

A number of theoretical explanations for these less successful results can be given. The true reason in a given case will, however, remain only a speculative guess. The cyst may not shrink if the solid or mainly calcified part of the tumor represents its major component or if the cyst is walled in by the sella itself rather than secreting endothelium (the solid parts of the tumor were not influenced by this kind of irradiation because of the $1.1 \mathrm{~mm}$ half-life decay of the radiation); or if the yttrium-90 leaks out of the cyst into the subarachnoidal space through the puncture hole. Thus far this has been excluded by gamma camera monitoring; it is doubtful whether this examination is enough to indicate the leakage, and we plan to measure the beta irradiation of the cerebrospinal fluid the day after the operation. The ethylene diamine tetra-acetic acid content of the positive contrast material might also decrease the effect of ${ }^{90} \mathrm{Y}$ in cases where cystography is performed.

Frequently a new cyst or cysts develop later; however, these clinically recurrent cysts in most cases have not originated from the cysts previously irradiated by yttrium-90. Hence "recurrent cysts," defined as those that reappear following initial response to treatment, should be differentiated from "successive cysts," which are actually new cysts that develop in polycystic craniopharyngiomas, usually several years posttreatment. Such successive cysts should be treated with a successive yttrium-90 implantation. However, we believe that multicystic craniopharyngiomas (when at least two or more cysts are present) require separate calculations and puncture. Cyst subtypes do not show significantly different response to treatment; however, small solitary cysts and adamantinous tumors react more to ${ }^{90}$ Y-STAIR, whereas the "mixed type" consisting of solid portions, the squamous type, and large cysts are less responsive.

The shrinkage of the cyst following ${ }^{90} \mathrm{Y}$-STAIR or other beta-emitting radioisotopes begins after several months and becomes stable after 6 months to 1 year.[3,13,34,40,42,44,45] From our repeated CT measurements we concluded that the time course of shrinkage of craniopharyngioma cysts following ${ }^{90} \mathrm{Y}$-STAIR might be expressed mathematically by the formula $0.73 \mathrm{X} \mathrm{e}^{-0.62 \mathrm{X} \mathrm{T}}+0.27$, where "e" is the 
basic number of natural logarithm and " $\mathrm{T}$ " is the time expressed in months. Figure 3 shows the duration of VR following ${ }^{90}$ Y-STAIR based on CT measurements (continuous curve) and estimated by our formula (dotted line).

Shrinkage of the cyst results in the improvement of both neurological and ophthalmological symptoms. Subsequent surgery, external irradiation, or shunting procedures may also contribute to the results of ${ }^{90} \mathrm{Y}-\mathrm{STAIR}$.

The radiation dose used in previously reported series ranges from 50 to $1000 \mathrm{~Gy}$, and the most accepted value is $200 \mathrm{~Gy}$.[32,40] We have been applying a 302 Gy mean radiation dose to the cyst wall. We plan to lower the radiation dose to 200 Gy or less in cases in which the cyst is adherent to the optic pathways or to hypothalamic structures. Experience from gamma knife radiosurgery indicating that doses more than 8 to 10 Gy may damage optic pathways should be considered when planning the dose in intracavitary treatments. The third, fourth, and fifth cranial nerves exposed to a dose from 4.5 to $30 \mathrm{~Gy}$ did not develop signs of neuropathy.[25]

The prognosis was good only when an intact optic disc or slight temporal pallor was seen.[12] Vision improved in 11 of 18 patients with intact optic discs or slight temporal pallor of the discs at the time of treatment. In most cases the lack of the ophthalmological improvement may be explained by the fact that the isotope was implanted at a late stage of the disease. The optic disc in these patients was pale or frankly atrophic. In cases in which the duration of the preoperative visual impairment was less than 1 year, improvement was still possible.[14,39] Any changes of visual function due to treatment usually occurred between 2 weeks and 6 months after yttrium-90 implantation.

The ${ }^{90} \mathrm{Y}$ irradiation prevents cyst fluid formation and will result in shrinkage of the cyst. To analyze the mode of action it is important to know the cause of the cyst formation in craniopharyngiomas. Large cysts may develop due to degenerative changes in the stroma with maturation and accumulation of sloughed-off squamous epithelium.[39] In addition, craniopharyngiomas have special fenestrated capillaries that might enable plasma proteins and fluid to escape more readily into the extravascular spaces. Our immunohistochemical and electron microscopy investigations revealed that the tumors might have a mucus-secreting component.[47]

After beta irradiation with yttrium-90 for 10 days and penetration 3 to $4 \mathrm{~mm}$ into the tissues, the lining epithelial layer of the cyst wall is destroyed, and further proliferation of tumor cells is inhibited. In specimens obtained from autopsy, a large amount of collagen fibers with focal hyaline degeneration was present in the cyst wall. Proliferation of the intimal cells and narrowing of small vessel lumens by subendothelial connective tissue occurred as well. Considering that fibrous tissue is more susceptible to shrinkage, the fibrosis induced by radiation with destruction of the squamous epithelium and vascular changes might explain the reduction of cyst volume and diminished fluid secretion after yttrium-90 treatment.[46]

Both the data from the literature and our findings prove that intracavitary instillation improves the rate of survival and quality of life in these difficult cases.

\section{CONCLUSIONS}

Our long-term results support the view that intracavitary ${ }^{90} \mathrm{Y}$ irradiation is a minimally invasive and very effective method of treatment for craniopharyngioma cysts. Because of the physical characteristics of 
beta irradiation, its effect is limited to the cystic part of the tumor; thus, the best result can be expected in solitary cysts.

During our more than 20-year follow-up period, an average of $75 \%$ shrinkage of the initial cyst volume was observed. In 18 cases the reduction was more than $91 \%$, and the cyst disappeared totally in 11 cases. The time course of VR sometimes takes a year and can be expressed mathematically by the formula of $0.73 \mathrm{X} \mathrm{e}^{-0.6 \mathrm{X} \mathrm{T}}+0.27$, where " $\mathrm{e}$ " is the basic number of natural logarithm and " $\mathrm{T}$ " is the time expressed in months. Because of the low operative mortality and morbidity rates, this method is an indispensable contribution to the multimodality treatment of cystic craniopharyngiomas.

\section{Acknowledgments}

The authors express their thanks to Drs. Ladislau Steiner and Dhereerenda Prasad of the University of Virginia Health Sciences Center for their advice and assistance in revising the manuscript.

\section{References}

1. Backlund EO: Colloidal radioisotopes as part of a multi-modality treatment of craniopharyngiomas. J Neurosurg Sci 33:95-97, 1989

2. Backlund EO: Stereotaktik behandling av kraniopharyngeom med intracystiskt ${ }^{90} \mathrm{Y}$ extern ${ }^{60} \mathrm{Co}$ Bestraling. Stockholm. Doktor-thesis, 1972

3. Backlund EO, Axelson B, Bergstrand CG, et al: Treatment of craniopharyngiomas--the stereotactic approach in a ten to twenty-three years' perspective. I. Surgical, radiological and ophthalmological aspects. Acta Neurochir 99:11-19, 1989

4. Badmaev KN, Balamutova HP: [On the problem of neurosurgical treatment of patients with craniopharyngiomas.] Vop Neirokhir 33:13-16, 1969 (Rus)

5. Balachandran S, McGuire L, Flanigan S, et al: Bremsstrahlung imaging after ${ }^{32} \mathrm{P}$ treatment for residual suprasellar cyst. Int J Nucl Med Biol 12:215-221, 1985

6. Bond WH, Richards D, Turner E: Experiences with radioactive gold in the treatment of craniopharyngioma. J Neurol Neurosurg Psychiatry 18:30-39, 1965

7. Campbell JB, Hudson FM: Craniobuccal origin signs and treatment of craniopharyngiomas. Surg Gynecol Obstet 111:183-191, 1960

8. Csanda E: Early and late brain edema following focal high dose irradiation, in Szikla G (ed): Stereotactic Cerebral Irradiation: Proceedings of the INSERM Symposium on Stereotactic Irradiations Held in Paris (France), 13 July 1979. INSERM Symposium. No.12. Amsterdam: Elsevier, 1979, pp 137-147

9. Fig LM, Shapiro B, Taren J: Distribution of [32P]-chromium phosphate colloid in cystic brain tumors. Stereotact Funct Neurosurg 59:166-168, 1992

10. Gahbauer H, Sturm V, Schlegel W, et al: Combined use of stereotactic CT and angiography for brain biopsies and stereotaxic irradiation. AJNR 19:715-718, 1983 
11. Georgi P, Strauss V, Sturm H, et al: [Pre and intraoperative determination of craniopharyngioma cysts.] Nucl Med 19:187-190, 1980 (Ger)

12. Gonzales-Feria L, Pedraza Muriel V, Ginoves-Sierra M: [Treatment of recurrence of cystic craneopharyngeom [sic] with stereotaxic inyection [sic] of Au 198.] Rev Esp Otoneurooftalmol 34:83-88, $1976(\mathrm{Sp})$

13. Guevara JA, Bunge HJ, Heinrich JJ, et al: Cystic craniopharyngioma treated by 90 yttrium silicate colloid. Acta Neurochir Suppl 42:109-112, 1988

14. Hajda M, Pásztor E: Significance of the appearance of the optic disc for predicting visual function following removal of pituitary adenomas. Neurol Medicochir 23:561-565, 1983

15. Huk WJ, Mahlstedt J: Intracystic radiotherapy $\left({ }^{90} \mathrm{Y}\right)$ of craniopharyngiomas. CT-guided stereotaxic implantation of indwelling drainage system. AJNR 4:803-806, 1983

16. Julow J, Drasny G, Lányi F, et al: [Use of microcomputer of intracavital radiotherapy of cystic craniopharyngiomas with ${ }^{90}$ Yttrium silicate colloid. Ideggyógyászati Szemle 40:547-552, 1987 (Hung)

17. Julow J, Lányi F, Hajda M, et al: Further experiences in the treatment of cystic craniopharyngiomas with yttrium 90 silicate colloid. Acta Neurochir Suppl 42:113-119, 1988

18. Julow J, Lányi F, Hajda M, et al: [Intracavital radiotherapy of cystic craniopharyngioma with intracystic installation of ${ }^{90}$ Y silicate colloid.] Ideggyógyászati Szemle 38:5-13, 1985 (Hung)

19. Julow J, Lányi F, Hajda M, et al: The radiotherapy of cystic craniopharyngioma with intracystic installation of ${ }^{90}$ Y silicate colloid. Acta Neurochir 74:94-99, 1985

20. Klar E: Zur gezielten Punktionsbehandlung bestimmter Hirntumoren. Lagenbecks Arch Klin Chir 276:117-121, 1953

21. Kobayashi T, Kageyama N, Ohara K: Internal irradiation for cystic craniopharyngioma. J Neurosurg 55:896-903, 1981

22. Kobayashi T, Negoro M, Asano Y, et al: [Conray cystography and volumetry of the cysts using computed tomography.] Progr Comput Tomogr 2:101-105, 1980 (Jpn)

23. Kodama T, Matsukado Y, Uemura S: Intracapsular irradiation therapy of craniopharyngiomas with radioactive gold: indication and follow-up results. Neurol Med Chir 21:49-58, 1981

24. Lange M, Kirsch CM, Steude U, et al: Intracavitary treatment of intrasellar cystic craniopharyngeomas with 90-yttrium by trans-sphenoidal approach--a technical note. Acta Neurochir 135:206-209, 1995

25. Leber KA, Berglöff J, Langmann G, et al: Radiation sensitivity of visual and oculomotor pathways. Stereotact Funct Neurosurg 64 (Suppl 1):233-238, 1995

26. Leksell L, Backlund EO, Johansson L: Treatment of craniopharyngiomas. Acta Chir Scand 133:345-350, 1967

27. Leksell L, Liden K: A therapeutic trial with radioactive isotopes in cystic brain tumor, in 
Radioisotope Techniques: Medical and Physical Applications. London: H.M. Stationery Office, Vol 1, 1951 [Ref. unverified]

28. Lindgren E, Westberg G: Radioactive bismuth phosphate for the treatment of craniopharyngioma. Acta Radiol Ther Phys Biol 2:113-120, 1964

29. Loevinger R, Japha EM, Brownell GL: Internally administered isotopes, in Hine GJ and Brownell GL (eds): Radiation Dosimetry. New York: Academic Press, 1956, pp 823-850

30. Lunsford LD: Stereotactic treatment of craniopharyngioma: intracavitary irradiation and radiosurgery. Biweek Rev Clin Neurosurg Pract 11:1-6, 1989

31. Lunsford LD, Gumerman LW, Levine G: Stereotactic intracavitary irradiation of cystic neoplasms of the brain. Appl Neurophysiol 48:146-150, 1985

32. Lunsford LD, Levine G, Gumerman LW: Comparison of computerized tomographic and radionuclide methods in determining intracranial cystic tumor volumes. J Neurosurg 63:740-744, 1985

33. McGuire EL, Balachandran S, Boyd CM: Radiation dosimetry considerations in the treatment of cystic suprasellar neoplasms. Br J Radiol 59:779-785, 1986

34. Munari C, Landre E, Musolino A, et al: Long term results of stereotactic endocavitary beta irradiation of craniopharyngioma cysts. J Neurosurg Sci 33:99-105, 1989

35. Musolino A, Munari P, Blond S, et al: Traitment stereotaxique des kystes expansifs de cranio-pharyngiomes par irradiation endocavitaire Beta $\left({ }^{186} \mathrm{Re},{ }^{198} \mathrm{Au},{ }^{90} \mathrm{Y}\right)$. Neurochirurgie 31:169-178, 1985

36. Netzeband G, Sturm V, Georgi P, et al: Results of stereotactic intracavitary irradiation of cystic craniopharyngiomas. Comparison of the effects of yttrium-90 and rhenium-186. Acta Neurochir Suppl 33:341-344, 1984

37. Overton MC III, Scheffel DD: Recurrent cystic formation in craniopharyngioma treated with radioactive chromic phosphate. Case report. J Neurosurg 20:707-710, 1963

38. Pan DH, Lee LS, Huang CI, et al: Stereotactic internal irradiation for cystic craniopharyngiomas: a 6 year experience. Stereotact Funct Neurosurg 54/55:525-530, 1990

39. Petito CK, De Girolami U, Earle KM: Craniopharyngiomas: a clinical and pathological review. Cancer 37:1944-1954, 1976

40. Pollack IF, Lunsford LD, Slamovits TL, et al: Stereotaxic intracavitary irradiation for cystic craniopharyngiomas. J Neurosurg 68:227-233, 1988

41. Pollock BE, Lunsford LD, Kondziolka D, et al: Phosphorous-32 intracavitary irradiation of cystic craniopharyngiomas: current technique and long-term results. Int J Radiat Oncol Biol Phys 33:437-446, 1995

42. Rähn T: Gamma knife radiosurgery and intracystic colloidal isotope treatment of craniopharyngiomas, in Broggi G (ed): Craniopharyngiomas. Surgical Treatment. Springer-Verlag, 1995, pp 120-125 
43. Schaub C, Bluet-Pajot MT, Videau-Lornet C, et al: Endocavitary beta irradiation of glioma cysts with colloidal ${ }^{186}$ rhenium, in Szikla G (ed): Stereotactic Cerebral Irradiation. Proceedings of the INSERM Symposium on Stereotactic Irradiations Held in Paris (France), 13 July 1979. INSERM Symposium No. 12. Amsterdam: Elsevier, 1979, pp 293-302

44. Strauss L, Sturm V, Georgi P, et al: Radioisotope therapy of cystic craniopharyngiomas. Int J Radiat Oncol Biol Phys 8:1581-1585, 1985

45. Sturm V, Rommel T, Strauss L, et al: Preliminary results of intracavitary irradiation of cystic craniopharyngiomas by means of stereotactically applied ${ }^{90}$ yttrium. Adv Neurosurg 9:401-404, 1981

46. Szeifert GT, Julow J, Slowik F, et al: Pathological changes in cystic craniopharyngiomas following intracavital 90yttrium treatment. Acta Neurochir 102:14-18, 1990

47. Szeifert GT, Julow J, Szabolcs M, et al: Secretory component of cystic craniopharyngiomas. A mucino-histochemical and electron-microscopic study. Surg Neurol 36:286-293, 1991

48. Szikla G, Musolino A, Miyahara S, et al: Colloidal rhenium 186 in endocavitary beta irradiation of cystic craniopharyngiomas and active glioma cysts. Long term results. Side effects and clinical dosimetry. Acta Neurochir Suppl 33:331-339, 1984

49. Trippi AC, Garner JT, Kassabian JT: A new approach to inoperable craniopharyngiomas. Am J Surg 118:307-310, 1969

50. van den Berge JH, Blaauw G, Breeman WAP, et al: Intracavitary brachytherapy of cystic craniopharyngiomas. J Neurosurg 77:545-550, 1992

51. Voges J, Sturm V, Lehrke R, et al: Cystic craniopharyngioma: long-term results after intracavitary irradiation with stereotactically applied colloidal $\beta$-emitting radioactive sources. Neurosurgery 40:263-270, 1997

52. Volkov AA, Vaskin IS, Zobina MM, et al: [The use of colloidal radioactive isotopes for radiotherapy of craniopharyngiomas.] Med Radiol 8:23-29, 1963 (Rus)

53. Wycis HT, Robbins R, Spiegel-Adolf M, et al: Studies in stereoencephalotomy III. Treatment of a cystic craniopharyngioma by injection of radioactive $P^{32}$. Confin Neurol 14:193-202, 1954

54. Zeng-Min T, Zong-Hui L, Gui-Quan K, et al: Stereotactic intracavitary irradiation of huge cystic craniopharyngiomas. Stereotac Funct Neurosurg 59:205, 1992 (Abstract)

Manuscript received September 22, 1997.

Accepted in final form November 20, 1997.

The major part of this article was presented on July 14, 1994, in conjunction with Professor Shigeharu Suzuki's inauguration into the Department of Neurosurgery of Hirosaki Medical School, Japan.

This work was supported by the H. M. of Welfare 028/966.

Address reprint requests to: Jenö Julow, Dr. med. habil., St. John's Hospital, Department of 
Neurosurgery, H-1125 Diósárok út 1, Budapest, Hungary. email: h12494jul@ella.hu 